\title{
Teaching and Knowing beyond the Water Cycle: What Does It Mean to Be Water Literate?
}

\author{
Alison J. Sammel1, Dena W. McMartin² \\ ${ }^{1}$ Education and Professional Studies, Griffith University, Gold Coast, Australia \\ ${ }^{2}$ Associate Vice-President (Academic and Research), University of Regina, Regina, Canada \\ Email: a.sammel@griffith.edu.au, Dena.McMartin@uregina.ca
}

Received 15 April 2014; revised 19 May 2014; accepted 2 June 2014

Copyright (C) 2014 by authors and Scientific Research Publishing Inc.

This work is licensed under the Creative Commons Attribution International License (CC BY). http://creativecommons.org/licenses/by/4.0/

(c) (i) Open Access

\begin{abstract}
Water is an extraordinary thing: it is the key to the chemistry of life. If it wasn't for water's unique properties, such as its abilities to dissolve other substances, life could not exist on our planet. Indeed, life was thought to have started in water and currently more than half of the plant and animal species live in water. On land, plants and animals need water for their existence, as the ability of water to disassemble and rearrange other molecules is essential to all daily actions. As humans, our bodies consist of about $80 \%$ water when we are babies, to around $60 \%-65 \%$ as adults. The human brain is about $85 \%$ water. Even though this simple polar molecule is one of the most prized possessions in the universe, what do people know about water? What does it mean to be water literate? In this paper, we explore what it means to be water literate in the fields of engineering and in science education. We will compare this theoretical understanding with what engineering and science education students actually know about water. We finish with recommendations to increase student's literacy in water.
\end{abstract}

\section{Keywords}

Science Education, Engineering Education, Water Literacy, Scientific Literacy

\section{Introduction}

Water is understood as the gold of this century. This simple compound of two hydrogen and one oxygen atom bonded to form a polar molecule is one of the most prized possessions in the universe. But does the average person appreciate this? What do people know about water and what does it mean to be water literate? Would in- 
creasing the focus on water related concepts and issues in science education be context for developing scientific literacy in the general populous? To explore these questions, this paper will investigate how water is labeled and what water literacy means in the fields of engineering and in science education. We will compare this theoretical understanding with what engineering and science education students actually know about water. We finish with recommendations to increase student's literacy in water.

\section{Understanding Water and Its Management}

In Western societies water is mostly given the label of being a natural resource. And like most resources it is understood that it needs to be managed. Based on the premise that good information leads to good planning, the water industry has heavily focused on scientific facts to make decisions (AWA/Deloitte, 2011). However, resource management policies and plans based on scientific and technical knowledge of water have not always been successful at ensuring the water needs of people (Muro \& Jeffrey, 2008). With pressing concerns of social justice and climate change, the water industry is beginning to go further afield for good information and is becoming more holistic in its thinking. Understanding water and its associated issues cannot be based solely on science and technical expertise (Muro \& Jeffrey, 2008; The Alliance for Water Education, 2013). These authors believe that water needs to be understood within social, economic, political and environmental aspects of local and global societies as it affects people's livelihoods, the environment and all life.

To frame how water is understood in Australia, the Australian Water Association (AWA) conducted a survey in 2010 to identify and conceptualize key water issues (AWA/Deloitte, 2011). The results highlighted that water sustainability was the most important water issue in Australia. Adapting to the water implications of climate change was the second most pressing issue, and third was ensuring water security. The participants of this survey, who were people associated with the Australian water industry, commented that water security was being managed quite well (55\%), whereas only $41 \%$ understood water scarcity and planning as being handled well; and only $25 \%$ could see water sustainability as being well handled. To understand why issues of sustainability were most pressing, it is important to conceptualize what sustainability of water means. To this end the Australian Water Association describes sustainability as addressing social, economic and environmental issues in an integrated fashion. The organization suggests,

[water] sustainability has grown in meaning. Sustainability is about how water is managed in a sustainable, living environment. It's not just about the sustainability of their businesses, of infrastructure and of people, but about the role of water. Water industry leaders are thinking about sustainability in this broader sense; this is where thinking is heading (AWA/Deloitte, 2011: p. 10).

It is this holistic conceptualization of water and its management that has gained prominence in informing Australian policy, planning and debate. This understanding also highlights that knowledge of science and technology alone will not move us towards the goal of sustainability, as all parts of society must bring their knowledge base together to achieve this end. However, within the education contexts, is this transition from focusing on the science and technology of water to the cultural and environmental aspect being enacted? What do the formal education entities believe the next generation of citizens needs to learn to be knowledgeable, informed, and have a balanced understanding of water?

To frame how water is understood in Canada, it's important to go right back to the Constitution. Water is for all intents and purposes the responsibility of provinces, with a limited role for the federal government. Recent calls for a more holistic approach to water, even a national water strategy, are becoming stronger and more cohesive. For instance, in 2008, the Canadian Water Resources Association, a not-for-profit organization of water professionals, released a comprehensive document road mapping a way forward to national water resources management and policy (de Loë, 2008). The report was commissioned in response to calls from water scientists and engineers across the country attempting to navigate water allocation, quality and quantity challenges.

Prime within the call for a national water strategy in Canada are issues related to current and emerging threats to the Canadian water supply, as first outlined formally in the so-called "Threats" documents released by Environment Canada in 2004. As water-related issues related to a changing climate began to emerge and activities related to exploration and extraction of natural resources were on the rise, federal government scientists released a comprehensive report entitled, "Threats to Water Availability in Canada" (Environment Canada, 2004). The report is focused primarily on water quantity challenges, with a nod to the importance of sufficient water quality 
to maintain public health and safety, as well as the industrial processes upon which the economy continues to grow and depend.

Despite the rise of interest in and concern for water resources issues in the early 2000s, more recent Canadian government policies and decisions have reduced the communications power of and access to and amongst scientific and engineering experts. One prime example of this is a 2012 decision to effectively close and end all research activities in the Experimental Lakes Area (ELA) of northern Ontario. This world-class research facility comprises 58 small lakes available for ecosystem level studies to quantify and evaluate impacts of various chemicals, pollutants, agents, and meteorological events on water quality. The scientific community came out in force to support the ELA (www.saveela.org) and pointed to numerous globally-relevant scientific and engineering breakthroughs made possible by the ELA and that would no longer be feasible, economically viable, nor scale-appropriate for real-world water research (Beisner, 2012). World-renowned scientist, Dr. David Schindler, for instance, has conducted leading research on phosphates, ecosystem functions, and tar sands development and water impacts at the ELA since it opened in 1968 (Experimental Lakes Area, n.d.).

Politics aside, water resources availability, access, allocation, consumption and threats are well known within the scientific and engineering communities in Canada. Water is precious and limited resource in regions where the majority of the Canadian population lives. Within that context, engineering education forges on to engage and enervate students and young professionals to value water, learn how to optimally treat water for human consumption, treat and dispose of wastewaters produced by human activities, and investigate and innovate ever-improving ways to manage water resources and watersheds.

\section{Understanding [Water] Literacy}

Even though there is agreement that the general public needs to understand the science that surrounds them everyday, scientific literacy does not solely imply functional scientific literacy. Within Educational literature, concepts such as "scientific literacy" are being shown to be multi-layered and complex. While the term has come to have nuanced meanings, it still has the same agreed meaning as it did in when the National Research Council (1996) published the (American) National Science Education Standards stating "Scientific literacy is the knowledge and understanding of scientific concepts and processes required for personal decision making, participation in civic and cultural affairs, and economic productivity” (p. 22). The 2012 NRC report entitled A Framework for K-12 Science Education: Practices, Crosscutting Concepts, and Core Ideas also support this understanding and focuses on the importance of addressing both science knowledge and practice. Specifically, the National Research Council (2012) states that "the contribution of this framework is the provision of a set of scientific and engineering practices that are appropriate for K-12 students and moreover that reflect the practices routinely used by professional scientists” (p. 301). DeBoer (2000) and others over the years have extended this discussion to emphasise where and how to use scientific terminology, to pose and evaluate arguments based on scientific evidence and apply appropriate conclusions, to understand and develop abilities to engage the ways of working scientifically, such as to engage in inquiry, evaluate evidence, identify patterns and think scientifically. But in the end, the common assumption is that scientific literacy mostly implies an emphasis on scientific concepts and ideas (Eisenhart, Finkel, \& Marion, 1996).

Thankfully, a number of critiques have questioned the emphasis on conceptual understanding. The major critiques, in the field of education, against this common assumption of scientific literacy are:

- Conceptual knowledge and conventional scientific processes are foregrounded attributes in scientific literacy at the expense of skills such as reasoning and communication skills and exploring more socially and, I would add, environmentally, responsible science (AAAS, 1989; Dimick, 2012; Eisenhart, Finkel, \& Marion, 1996; Reveles, Cordova, \& Kelly, 2004).

- If conceptual knowledge is key, then who decides what type of knowledge the general public should have in relation to the vast breadth of scientific knowledge (Hodson, 1999; Reveles, Cordova, \& Kelly, 2004).

- Being scientifically literate needs to be situated within a collective experience, rather than being thought of as an individual attribute. A student who is simply a "receptor" of science facts' and is able to read, write and talk science is not necessarily scientifically literate, as they must also understand the fundamental conceptual, epistemic and social dimensions associated with the scientific community-they must appreciate the collective view of what it means to do science, of how to think, communicate and argue in the beliefs and language of science (Roth \& Lee, 2002). 
As such, for people to be understood as being scientifically literate in water, means they need to understand not just scientific facts about water, but they also need to understand the epistemology of science, what its goals are and how it operates, so they can appreciate both the positive and limitation of this scientific worldview. In this way, we may generate critical and creative thinkers who may indeed provide hope in becoming citizenry that will engage in attitude changes leading to ecological sustainable behavioural and most importantly, engage in the democratic processes available to them.

Outside of the field of Education, there are many in which governments and industries understand the concept of water literacy. The Australian Government relates water literacy with an improvement in the populist understandings of the properties of water; the biological, chemical and physical science concepts associated with water issues; and gathering statistics and facts to dispel misinformation associated with water science, management and use (Department of Sustainability, Environment, Water, Population and Communities, 2011). Others maintain that people need to understand water at the atomic-molecular level (changes of state and solutions) through to large-scale systems including watersheds, aquifers, and human water-purification and distribution systems (Covitt et al., 2009). These authors focus on ensuring students know how water moves through systems and how it interacts with other substances. Through their investigations with school-aged students they found two key principles they believe students must follow to gain water literacy. These were the ability:

1) To understand and apply the principles of the conservation of matter to water and substances within water.

2) To trace the movement of water and materials that water carries through visible and invisible parts of systems.

These points imply that as water and other materials cross the boundaries between visible and invisible forms they do not cease to exist, but can be traced through systems in their different forms. As such, water literate students will understand that every molecule of water moves through a cycle and stays in that cycle. Further, students will understand that other materials such as pollutants, bacteria, sediments and garbage enter the water cycle and can also be accounted for as they enter, travel with, and separate from the cycle.

The Alliance for Water Education takes a broader perspective than this focus on science knowledge and links water literacy to people understanding the intersection between water usage, their everyday life and being able to have an educated discussion around controversial issues associated with water. They maintain that being water literate means that students can calculate their individual water footprint and understanding that all foods and products required water in their production process. Not only should people understand how much water they use, but they should also understand what it means to have healthy watersheds. Alongside this, is the knowledge of how human and natural systems maintain those watersheds. The focus is therefore on individual and more localized understandings of water, its movement, and implications for making wise, sustainable choices for water conservation.

\subsection{What Water Literacy Means in Science Education in Australia}

In Australia science education is now governed by a National curriculum. The Australian Curriculum (Science) (referred to as ACS) guides what content is to be taught at each year level from kindergarten (referred to as Foundation Year) to grade 12. It is compulsory for all Australian teachers to use this curriculum and for every graduating student to have successfully met the competency requirements for each subject they have undertaken (ACARA, 2010). As such, to appreciate what competencies Australian students must successfully gain in relation to understanding water, it is important to examine what the ACS mandates the teachers' focus on.

Not only do Australian teachers and students have a mandatory focus on the specific science concepts set out in the ACS, but these concepts have also become what science education courses at Faculties of Education must also address. This has resulted in restricting teaching material at the pre-service level, as reduced contact hours and a mandate to cover the specified ACS concepts necessitates an almost exclusive focus on these particular science concepts and processes, to the exclusion of other critical and creative science pedagogies.

As the discipline of science is mandatory up to year 10, this paper will focus on the ACS from the Foundation year to year 10. Fundamentally, the ACS has 3 interrelated strands that explore Science Understanding (science content), Science as a Human Endeavour (how science relates to technology, environment and society) and Science Inquiry Skills (ways of working and thinking in science). These strands challenge students to explore science, its concepts, and nature through inquiry-based processes. The goal is for students to develop a scientific view of the world (ACARA, 2010). The Science Understanding component is divided up into Biological sciences, Chemical sciences, Earth and space sciences, and Physical sciences. There are 18 references in total 
relating to water within the Biological sciences, Chemical sciences, Earth and space sciences, and Physical sciences from the Foundation year to year 10. If there are interrelated curriculum requirements within the same year level and the same discipline, for example, Year 1 Biological sciences, then these have been recorded under one reference.

Six of these 18 references relate to Earth and space science. These include: seasonal changes and weather patterns (Foundation year); short and long term changes in weather (grade 2); water as a resource (Year 2); the transportation, management, daily use and conservation of water (Year 2); how water can change the Earth's surface over time (Year 4); droughts and floods (Year 6); the water cycle and changes of states, management and human impact (Year 7); and the causes and consequences of climate change and water (Year 10). Five of these 18 references relate to the Biological sciences. These include: understanding that water is a basic need for living things (Foundation year); structural features for obtaining water (plants) (Year 1); what happens when water requirements are not met (Year 1); adaptations of living things to survive (Year 5); how physical conditions affect survival (Year 6); how ecosystems change due to droughts and flooding (Year 9); and how multicellular organisms rely on coordinated and interdependent internal systems to respond to changes to their environment (Year 9). Interestingly, most of the above points are taught in grade 6 or less. Four of the 18 curriculum references relate to the Chemical sciences, topics include: how water changes when it is heated and cooled (Year 1 and Year 3); the properties and behaviours of solids, liquids and gases (Year 5); reversible and irreversible changes (Year 6); and the solubility of common materials in water (Year 6). Again, these topics occur in grade 6 or below. The last component within Science Understandings is the Physical sciences. There are 2 references to water in this section and they relate to how objects move through water (grade 2) and how water can be used to make electricity (grade 6).

Four of the 18 references relate to the strand Science as a Human Endeavour and are found within Year 5 - 7. The topics for this strand include: considering how best to ensure plant growth and making decisions about growing particular plants and crops (grade 5); looking at sustainable power sources from water; investigating early detection and management of catastrophic natural events; exploring institutions and locations where contemporary Australian scientists conduct research on catastrophic natural events (grade 6); and considering issues relating to the use, management, and recycling of water within a community (grade 7).

The last strand Science Inquiry Skills, provides suggestions about how a concept could be taught, but not the what. The what is explored in the other 2 strands as described above. This third stand mandates an inquiry based approach, rather than a chalk and talk model. From this perspective science education is underpinned by modeling thinking and acting like a scientist by testing predictions or hypotheses and drawing conclusions in response to a question or problem. These investigations can involve a range of activities, including experimental testing, field work, locating and using information sources, conducting surveys, and using modeling and simulations (ACARA, 2010). These investigations stress the process of collection and analysis of data and evidence but do not make any specific reference to content, such as the concept of water.

It seems that the content side of water is taught mainly in the lower years of schooling and the environmental and social sides to water are explored later. This could be due to the spiral nature of the curriculum, where concepts are taught in general, a big-picture pattern in the early years. These early ideas reflect concepts that students have seen or have some direct knowledge with, like weather patterns. These generalized concepts are then built upon adding more specific and focused conceptual understandings associated with water such as the water cycle. This specific knowledge reflects on and reinforces previous knowledge the students have gained in earlier years. In this way students can understand how the water cycle and weather patterns interrelate.

By embedding the Science as a Human Endeavour strand requirements after the Science Understandings strand requirements, it can be assumed that once students have a more detailed understanding of the scientific concepts associated with water, then they will be better able to place and discuss this science knowledge within larger socio-cultural frames. This supports a more individualized focus and indicates the desire for students to investigate the importance of water in their everyday lives. For example, in year 2 the curriculum seeks to capture interest by asking students to identify and describe the location of water in their personal environment (ACARA, 2010). In year 7 the ACS seeks to address the science of the water cycle and asks students to explore how human management has impacted this cycle. These examples imply that scientific knowledge can be incorporated into student's lives to change people's decisions and actions. However, we wonder if the assumption that increased knowledge actually does increase people's literacy and can influence decision-making and actions? 


\subsection{What Water Literacy Means in Engineering Education in Canada}

The goal of water sciences education in engineering is to advance the theoretical understandings of the chemistry and biology of water along with responsible resource management and proper application of the laws and policies that govern water management. Foremost is the application of this knowledge in professional situations when called upon to solve problems related to water quality, quantity, or sustainable resource use. Within the field of Engineering, water is understood primarily as a shared resource. It has been defined by different notions of "property" and as a consequence managed according to various governance regimes. Regimes can be generally classified as the state, the market, the consensus based and the empowerment approaches.

This understanding suggest that the rights, obligations and responsibilities associated with water rests with the holder, as long as that right does not interfere with the ability of others to exercise their own existing rights. Property rights associated with water are complex water moves through landscapes and can travel vast distances. To address issues of the abundance, scarcity and quality of water during the year, and to manage people's rights and responsibilities, infrastructure is needed to monitor, measure and account for the water that flows both above and below the land's surface. Relocation of water, its benefits, limitations and viability means that mechanisms are needed, these may be in the form of water laws, or agreements situated within communities.

Engineering education to build water literacy is focused on both content acquisition and content application. Therefore, students from all engineering disciplines expand their knowledge of general water chemistry and physics, hydrologic cycle, and benefits of good water management learned in primary and secondary schooling. The expanded knowledge delves deeper into cycling of not only water but also nutrients and contaminants during global water cycling, how chemistry and physics of water quality affect treatment options for producing water of sufficient quality for drinking, recreation, agriculture, and other uses, what water quality and quantity challenges may exist for supporting aquatic life in watersheds, improving resource management and understanding the concepts related to source water protection, the presence and both benefits and challenges related to microbial communities in water sources, and the political forces that affect water allocation and use.

The application of content by all engineering students is expected within the context of basic systems design and processes conventionally used for water and wastewater treatment and ecological management of water, including general knowledge around design for flood mitigation and water storage. Students specifically enrolled in environmentally-related engineering programming will learn to apply these same concepts but continue to build a deeper and more meaningful understanding throughout their programs, taking courses and performing laboratory exercises focused on design and innovation in their application of knowledge. Further, these students engage in focused coursework related to groundwater contamination; contaminant transport; application of microbial systems for remediation of water quality in both domestic and industrial settings; resource management for storm water design, flood mitigation and water storage systems; and ecological management including riparian area health assessments. This in-depth learning is intended to support students in their quest to apply content, but also to gain better understanding of how their designs and decisions can benefit society, protect populations and livelihoods, and influence both political and professional decision-making bodies.

Providing students an opportunity to flex their decision-making muscles in the water sciences while still in the safety of the ivory tower allows them to gain confidence and contextual knowledge about how their decisions can influence and impact decision-making on democratic society. Their expertise will be called upon to support the development and defense of federal and provincial policies and laws, as well as determining optimal balances amongst competing water users and allocation of resources. Further, as engineers, these students will have a voice in identifying the tenets of sustainability and equitable access rights surrounding issues of water resources management. They will also be responsible for advancing new and innovative methods for water management, treatment, protection, and valuation through systems such as cumulative effects assessments and monitoring of industrial, agricultural, domestic, ecological, and other competing consumers.

Within each of these key areas, learning activities occur that support student comprehension about water issues in general, but also how their decisions and designs may impact water resources in engineering practice. In part, these are taught to meet accreditation requirements from the Canadian Engineering Accreditation Board (CEAB), while further investigation into these is more relevant for those students who specialize in more water-relevant engineering disciplines. The CEAB criteria are established in reference to society's expectations of how engineers can serve and safeguard various publics, but also to emphasize the significant level of trust placed on those in the engineering profession to make intelligent decisions with lasting positive impacts on econo- 
my, environment, society, and technology.

As noted by the CEAB (2011), "The engineering profession expects of its members competence in engineering as well as an understanding of the effects of engineering on society. Thus, accredited engineering programs must contain not only adequate mathematics, science, and engineering curriculum content but must also develop communication skills, an understanding of the environmental, cultural, economic, and social impacts of engineering on society, the concepts of sustainable development, and the capacity for life-long learning” (CEAB 2011: p. 11). Further, the CEAB sets criteria to ensure that students build strong foundations across all engineering-related fields and do not over-specialize to the point of shortsightedness. Innovation and freedom to accommodate region-specific, expertise-specific, and competitive advantage in engineering education curricula are vital. Thus, transfer of information and application of knowledge in the water sciences will differ amongst the various engineering programs across Canada. However, all will include strong foundations in the development of basic understanding and context. Some will include specialization in support of developing students who are high quality decision-makers upon whom society can rely to make intelligent decisions and innovative designs.

In engineering education, it is vital to include a two-pronged approach that includes not only content acquisition, but also an understanding that permits intelligent application and innovation of that content into smart engineering design and problem solving.

\section{A Case Study about Water in Science Education in Australia}

To allow students develop water-related scientific literacy, we need teachers who are knowledgeable and capable of creating appropriate curriculum materials and designing stimulating classroom environments. Clearly, teachers play a pivotal role in developing and implementing classroom activities that enable students to develop their scientific literacy. As such, a necessary first step for the successful development and implementation of activities that promote scientific literacy is to ensure that teachers and pre-service teachers are themselves water literate. To provide a snapshot of water literacy in pre-service teachers, a case study was conducted in Semester one, 2011 at a large multi-campus university in Queensland, Australia. This study used an interpretative mixed methods approach. Interpretative mixed methods aligns with this research as it aims to "understand how individuals make meaning of their social world" and "allows for multiple views of social reality" (Hess-Biber, 2010: p. 104). The focus of this methodology is not specifically that it employs both qualitative (textual data) and quantitative analysis, but rather the standpoint that social reality is created through the interactions of individuals with others and with the world around them. It seeks to contextualize people's experiences. To this end, this research employed a survey method with quantitative measurement questions to frame the representative sampling while also employing qualitative questions to gain deeper insights into how the participating students understood the science, as well as the teaching and learning of concepts associated with water.

\subsection{The Participants}

The 32 participants were drawn from an undergraduate, pre-service teaching cohort in their third year of a Bachelor of Education (Primary). They were enrolled in their second, and last, science education course. The total number of students in the cohort that year was 79 . This represents a response rate of 40.5 per cent. There were only 32 students who attended the last lecture and all choose to complete the anonymous survey. Whilst gender and age data was not collected it can be assumed that the majority of respondents were female given over 95 per cent of the cohort were females.

\subsection{The Instrument}

The participating students were asked to complete a survey consisting of 14 questions to self-report on their knowledge and comfort with teaching about water. The survey investigated five themes: what pre-service teachers believe primary children know about water; where pre-service teachers believe primary children should learn about water; what purpose, values and behaviours should be taught to primary children in relation to water; what the pre-service teachers learnt about water and what they currently know; and lastly, what the pre-service teachers would like to know more about in relation to water. Table 1 shows the individual measures for each theme, the number of items within the questionnaire, and the scales used for each.

Data analysis occurred through an iterative process. For the scaled and closed questions, a frequency distribu- 
Table 1. Constructs of pre-service students water literacy.

\begin{tabular}{|c|c|c|}
\hline Construct & $\begin{array}{l}\text { Measured as... } \\
\text { (scale/open/closed question) }\end{array}$ & Number of Questions \\
\hline What pre-service teachers believe primary children know about water & Open ended questions & 2 \\
\hline Where pre-service teachers believe primary children should learn about water & Open ended questions & 2 \\
\hline \multirow{2}{*}{$\begin{array}{l}\text { What purpose, values and behaviours should be taught to primary children in } \\
\text { relation to water }\end{array}$} & Open ended questions & 3 \\
\hline & Scale (1 to 10$)$ & 1 \\
\hline \multirow{3}{*}{$\begin{array}{l}\text { What the pre-service teachers learnt about water and what they currently } \\
\text { know }\end{array}$} & Open ended questions & 3 \\
\hline & Scale (1 to 10$)$ & 1 \\
\hline & Closed questions & 1 \\
\hline \multirow{2}{*}{ What the pre-service teachers would like to know more about in relation to water } & Open ended questions & 1 \\
\hline & Closed questions & 1 \\
\hline
\end{tabular}

tion allowed for a structured analysis, and highlighted patterns and common themes. The data from each openended question was organised into a chart that allowed for an analysis of common themes and patterns, and from there, the frequency to which these theme were mentioned. Deviations to these patterns, interesting statements, and relationships between open-ended questions and the closed and scaled questions were explored. The results are communicated in relation to the above five themes.

\subsection{Reliability and Validity}

The process of developing the survey robustly explored and addressed issues of reliability and validity. To address validity, or the extent to which the survey measured what it was designed to measure, numerous steps were taken. Issues associated with content validity were addressed early in the development of the survey with insights emerging from field notes and informal semi-structured interviews with students around the teaching and learning of water and its related issues. Important issues also emerged from the literature review. The survey included all the identified issues and included multiple ways of measuring and recording students' opinion and experiences. Specific closed questions were asked, along with questions allowing for a range of responses to measure the strength of students feelings towards issues, as well as open-ended questions to formally encourage participants to report on issues they felt were important, and from their own point of view. Specific questions were adapted or were informed from measures found in related literature either in terms of the development of the measuring instrument or as a content source for a question. To address the reliability and face validity of the survey, in addition to the pilot work, colleagues and students (not enrolled in the target course) were asked for comments and suggestions. This encouraged the modification of questions so the participants could more easily understand them. The final survey was appropriate for the student body as it was of reasonable length, used familiar wording and was well presented. This face validity check also confirmed construct and content validity as feedback supported that the survey was reflective of the classifications and complexity of the five themes. Further, to facilitate reliable data, the survey was conducted during the semester period, so the respondents were still engaged with the teaching and learning of science education. An academic who was not teaching into that specific course gave instructions about how to complete the survey and its importance. Students were told that it was voluntary and anonymous.

\subsection{The Results}

The emerging results for the five themes highlight that in relation to what pre-service teachers believe primary children know about water, 13 participants suggested some aspect of the water cycle. For example, one respondent says, "rain comes from clouds, they may think it goes straight into the lakes and seas and not know about run-off”; another suggests "the water cycle. Evaporation + rain. I don't think kids know about plant transpiration + other ways the water gets back into the air"; and a third respondent states that students would know "where it comes from, how catchments are filled, and where rivers flow to and from." Five respondents said they believed children thought water comes from clouds or the sky. Almost as many respondents $(\mathrm{N}=12)$ believed children know of the practical applications of water in their everyday life. Examples were: "drink it, flush it, use it to 
brush, water the garden, swim in the pool and in the ocean”; “drinking, baths/showers, toilet, watering garden, and water conservation"; "we give it to pets"; and we drink it, cook with it, wash with it and play in the pool with it". Nearly half of the pre-service teachers $(\mathrm{N}=15)$ thought students knew where water was found or where it comes from. Although, when they expanded on this, only 3 wrote the word "dam", making specific reference to where drinking water in this catchment comes from. Others thought children would know more generalized forms of where water comes from and referred to beaches, rivers, oceans and lakes. Four respondents were specific and said they thought children would know water came out of taps. One student simply stated that children would know that water is wet. Two respondents were at cross-purposes as one said children would know water "runs out of taps or they drink whenever they want; it doesn't cost anything”. While the other suggested children know that "it comes from dams, to their house. They drink it, costs money". Yet another participant suggested children know "the process of water from rain to drinkable. How mother nature affects the behaviour of water".

An interesting pattern emerges from this data suggesting there is no overarching understanding of what these future teachers believe children know about water. The strongest suggestions were vague references to the water cycle, practical uses for water and where water can be found.

A key element to inquiry-based teaching is for teachers to be mindful of children's current knowledge around a topic. This allows the teacher to design activities and engage in conversations best suited to moving the students from their current ideas towards a more scientific understanding of the topic. Without a base guideline of what children know, designing units and lessons can become problematic for learning.

When asked about places where they believe children learn about water, 26 of the suggested teachers and schools, 14 said television, while 14 also made reference to family, friends or peers. Five suggested children learn about water from their general life experiences: "Drinking it, swimming in it". Asked about the purposes for learning about water, most pre-service teachers suggested conservation and sustainability issues $(\mathrm{N}=13)$. While ten participants believed it was to support the life of the students: "Part of a healthy diet".

In response to the question what they had learned at school about water, the predominant number of responses $(\mathrm{N}=18)$ made reference to the water cycle either simply stating "water cycle" or in descriptive responses such as "about precipitation + how clouds form + why it rains" and "evaporation, rain, clouds, etc.". Interestingly, even though 13 participants suggested the purpose of learning about water related to conservation and or sustainability, only nine commented on learning it themselves e.g. turning taps off, having shorter showers, and how much that little bit contributing to saving water". Two participants spoke of the chemical nature of water however, 7 said they learnt "very little" or that they "cannot remember".

When asked about the specific origin of their drinking water in their city. Slightly less than one third of the respondents $(\mathrm{N}=9)$ noted the correct dam. A small number of participants indicate not knowing where their water came from $(\mathrm{N}=6)$. The largest proportion of the respondents provided generic answers, including dams/ reservoirs $(\mathrm{N}=8)$, catchments $(\mathrm{N}=2)$, rivers $(\mathrm{N}=1)$, and the sky $(\mathrm{N}=3)$. Further, when asked about their knowledge of specific water education programs, over half suggested $(\mathrm{N}=17)$ they did not know of any, where are as 15 , provided the name of a program. This suggests that the pre-service teachers would need to become more familiar with online and local resources to support their science pedagogies.

The participants were asked to respond to the question about anticipated values: "What values do you think students would have if they were water smart/respected water?” A considerable number of students $(\mathrm{N}=14)$ wrote about saving, conserving water, using it responsible, or reducing water usage (i.e., be "water wise"). For example, one pre-service teacher noted that students "would not waste water, they would practice conserving water, and [would be] reducing water usage.” Another provides some specific examples about how to conserve water: "Save water by having 4 min showers, water plants in dedicated times, i.e., not at midday". Ten participants wrote about students valuing or developing a general respect for or appreciation of water. For example, the respondents noted that "[students] would have a lot more appreciation for water and how it is an important resource in order to survive" or "[students would] understand how wonderful water is... and what it does for our health and wellbeing." Water's ability to be recycled and re-used was noted explicitly by four participants, stating "[students, their parents] would wash cars with recycled water or water plants with laid over drinking water". The same number of respondents $(\mathrm{N}=4)$ also exhibited a concern or empathy for life. For example, one respondent noted that "[students] would be living a life that values the overall wellbeing of humans, animals, nonanimals, plants etc."; another wrote that students would exhibit "empathy to others with lack of water"; and a third wrote that "[students would] understand how wonderful water is, not only on a large scale but on an individual level.” Finally, four respondents articulated values with respect to the human impact on water and suggest- 
ed that students would participate in preventing pollution. For example, respondents noted that students would "understand the impact our daily lives have on water"; that children need to "prevent pollution of our waterways," and "not throw out water bottles in bin."

Asked about specific behaviors that water-smart and water-respectful students would exhibit, respondents reiterated their answers for the question about values. For example, one respondent noted that students would "would have shorter showers + turn from running taps; turn taps off, properly so they don't drop etc.”. It was also stated that children "would learn to practice the little things such as not leaving the tap running while brushing teeth." Others suggested that students "may not waste water, conscious of how they use it; not dumping rubbish in the waterways" or "would be able to realize the importance of saving water. Shorter showers and minimal water use when washing dishes."

Finally, when the pre-service teachers were asked what they would like to learn about water, and were given eleven choices to choose from ranging from science concepts; social, political, economic, environmental and community implications or issues, political eight respondents made no suggestion. The remaining respondents tended to pick items from the list of topics that they would "feel comfortable teaching about," generally noting those that they had not ticked. About equal numbers of respondents listed the political implications of water ( $\mathrm{N}$ $=4)$, indigenous ways of knowing around water $(\mathrm{N}=5)$, governmental plans/uses with water $(\mathrm{N}=4)$. One preservice teacher noted wanting to know about "economic \& political concerns, incl. water security [like food security] \& how communities use it, indigenous ways of understanding water." Others suggested that they "would like to learn all of the above issues to take the typical teaching beyond the water cycle" or wanted to "understand where water comes from, and how this affects droughts and floods to understand human impact on the water supply.”

\subsection{Implications from the Study}

So what does this study highlight? If students need to have larger picture visioning about water with multiple knowledge bases to fully engage in vital community discussions, and to incorporate water conservation practices within their daily lives, then so will their teachers. This small study highlights that the majority of these 32 future teachers have only learnt about basic scientific concepts of water within their own schooling. They also believe their future students have the same basic understanding of the water cycle. These understandings are consistent with the Science Understandings strand of the ACS. To be scientifically literate in water, teachers and students need to understand basic water concepts such as the water cycle, but this information alone would not be enough. The participants commented on learning about water conservation, and believed the majority of values and behaviours students should develop relate to practical aspects of water conservations, such as turning off taps, etc. These understandings support both the goals of the Science Understandings and the Science as a Human Endeavour strands of the ACS as they both focus on the science, and technology of water sustainability and conservation.

Theoretically the ACS aims to provide an understanding that the environment is not infinitely resilient and requires careful management. It is the believed that students need not only an understanding of the basic scientific and technological concepts associated with water, but also an increased understanding of their effects on the availability and quality of water, and the need for them to adopt greater individual and community responsibility for its use. The emphasis is on personal responsibility and good environmental [water] stewardship practices. It is assumed that this increased awareness and scientific understanding will guide practical judgments and promote changes in individual behaviour. However, behavioural change research emphasises that this link is not as causal. Educational research has also shown that just because you teach it, does not mean students will change their behaviours to reflect what has been learnt, even if they believe in the concepts and philosophies taught. Long term modeling specific practices, and deconstructing beliefs and behaviours have shown potential to alter behaviour. However, this deconstruction of students' thought processes and the long term modeling of more appropriate practices are not reflected within the curriculum.

This focus on increasing individual awareness, understanding and interactions with the science and technology behind water varies with what the larger social framing of water and its management. Even though there are similarities, such as an understanding of the science, the focus on individual use may help students see how water impacts their lives, but it may not help them connect to larger economic, social and political perspectives associated with water in their local, national and global communities. It is at this larger social level where national 
debates about water will occur and vital decisions will be made. Students need to be knowledgeable of issues holistically and have the stills and ability to fully engage in vital discussions and make informed choices of how to act on those issues.

Even though both the ACS and the voices of the participating pre-service students highlight the need to relate scientific concepts to the lives of students, they both do so from an Enlightenment view of scientific problems. Both do not acknowledge that knowledge and knowledge production are always part of a larger network of power relations that become the site of conflict over what social knowledge should be constituted and to what end. They ignore important dimensions of social and environmental issues that involve emotional concerns, beliefs, aspirations, aesthetics and vested interests. Even though they are based on the foundation that scientific literacy is essential for all students, regardless of gender and cultural background, they do not acknowledge that dominant hegemonic discourse constructs societies that are structurally unequal in power which advantages or disadvantages certain groups and legitimizes hierarchies of beliefs and values. If hegemonic understanding is the main focus of what is taught, then what fails to be known is the prevailing invisible social, cultural or political conditions that create and seek to maintain the political and economic status quo around controversial issues. Accordingly, both the participants and the ACS do not suggest the exploration of how these socio-political interests inevitably play a role in determining the nature and shape of scientific and social knowledge and therefore contribute in the way the world is created and understood. To this end, what is left out highlights that education can never be neutral as dominant hegemonic educational agendas seek to maintain and reproduce a particular social structure. Both the voices of the participants and the ACS can be viewed as ensuring scientific literacy about water takes place within safe and politically acceptable limits. Subsequently, the curriculum mandates hegemonic beliefs and values, ignores the ways in which science, by way of the government curriculum, does not address root causes of social and environmental injustices or work towards anything but a marginal understanding of science and its social implications.

This is not to say that a critique of hegemony does not occur within the lived experience of formal science education. There is no directive in the curriculum stating that ideological, political, social and economic ways of exploring water are not allowed within the scientific framing; they are just not formally encouraged. However, if both the participants and the ACS support this invisible hegemonic agenda then this understanding becomes the benchmark for good teaching about water. It also becomes the basis for "legitimately" disqualifying and marginalizing of any alternative practices that may explore more deeply the role politics, economics, and science itself plays in promoting and maintaining social and environmental problems and injustices around water issues. This usually manifests itself in accusations of deviancy, unprofessionalism and attempts to "indoctrinate" when teachers or students seek to explore in theory or action, the deeper underlying connections between economic and/or political policies and social or environmental injustices. As such, teachers and students are expected to follow the hegemonic agenda in order to be view as successful with the educational system.

\section{A Case Study about Water in Engineering Education in Canada}

Compared to the above survey and case discussion of water in pre-service science teacher education, this case study of perspectives and perceptions about water in engineering education is limited. However, several key features and concepts emerged through personal interviews and email survey results with 15 post-graduate engineering students and early-career professionals. Engineering participants noted three key themes of import for both engineering education and practice. These are: 1 ) water as a health need and challenge; 2 ) water as an enigma through the lens of both treatment requirements and challenges, as well as how appearance can be deceiving; and 3) water as a shared resource (the balance and competition for meeting ecosystem, human, industrial needs).

The responses corresponding to the first theme, water and its role in health, are interesting in that engineers typically do not work directly with health, per se, although engineering education has more recently striven to include and emphasize how engineering works do, in fact, directly impact and can greatly improve public health and safety. Engineering technologies, problem solving, and activities promote the production of high quality water resources for maintaining or improving health. Water as a healthy resource has long been the purview of epidemiology and toxicology sciences, with engineering education focusing more on the "what" or "how" rather than the "why" of water treatment for production of safe drinking water. Comments from those surveyed including, "water is a right" and "water is essential for healthy living", demonstrate that young engineers have a 
clear understanding and value for the context in which they work with water and in the provision of safe water for communities and individuals. Again, from the survey results, this perspective appears primarily as a human health issue, and was not explicitly noted by respondents to include or intend to include other mammals or the biological world in general. Although all survey participants $(100 \% ; n=15)$ specifically mentioned health as a key water theme, each respondent had a unique way of expressing how health and water are linked and how these are addressed or are important in the engineering context.

Water as a challenge for design, optimization, maintenance, and operation of treatment technologies, was also mentioned by the participants in this case study. Environmental (and civil) engineering curricula include several opportunities for formal education in water and wastewater treatment technologies, design, and practice. As engineers, we learn early and often that some water sources are classified as "stubborn" or "recalcitrant" giving them an anthropomorphized character that is less chemical in nature than is the reality. The majority of survey respondents (13 of 15) noted that water, for them, is an engineering problem to solve. That is, water seems to have a personality requiring special attention to specific and unique treatment designs and ideas for producing a high quality drinking water. Some waters are "just impossible" or represent "a never ending problem" that, despite all engineering efforts, innovations, and investments, "just cannot be treated using typical designs and plant [configurations]". Further, water is considered to be "tricky" (yet another example of how engineers may anthropomorphize water) in that it can look as though it's safe and clean, yet may harbor dangerous and potentially lethal pathogens or chemicals. Alternatively, water that appears dirty (colored) or smelly (odorous) may in fact be perfectly safe for human consumption, despite not being particularly attractive from an aesthetic perspective. Because of the novel design challenges that hard-to-treat waters present to engineers, they are the subject of boutique conferences, webinars, and special courses. It is impossible to fully address in the classroom all water source challenges and issues that young engineers will face in the field. Our young engineers clearly see water treatment and design as a challenge for engineering education and practice.

Finally, and perhaps most encouragingly in the educational outcomes framework, is the recognition that water is a shared resource that is not solely the purview of humans; for our sole and (top of the food chain) use, pollution, consumption, activity and growth. Eleven of 15 respondents (73\%) noted that water is essential as a common good and an ecosystem need. That aquatic life, environmental processes, and ecosystems have a right to water and cease to function without adequate access to water. Balance in how we allocate, consume, transfer and transport, and value water as a shared resource was noted as a primary outcome of engineering education and a continued perspective in young engineers' professional experiences to date.

One theme not addressed in the above that did appear in $40 \%$ (6 of 15) of responses can be represented by the following statement from one survey participant: "we need a better way to manage water in this province". Further commentary on this subject seems to indicate support for, or a new understanding of the value of, a national water strategy that would not only enhance water management processes and legal structures, but also help to balance the many competitors for water under current industrial and economic growth strategies. Additionally, two comments (of 6) within this frame of discussion noted challenges and concerns related to the commoditization and commercialization of water in Canada.

Other unique or individual responses to questions about how water is important to engineering activities and/ or engineering education included comments such as, “I hadn’t realized how much water we use in engineering” and "does anyone really understand how much water is needed for all the new potash mines we're planning to build?”. These comments may be taken as support for development of cumulative water use and resource management policies. However, they may also be viewed as part of the overwhelming learning curve about water and its uses as newly minted engineers start their careers. Hearing about something and seeing it in action can be very different experiences. Being on site to witness and design systems that use vast quantities of water may simply be one of those experiences that transitions from numbers on a page to practice in reality.

\section{Science Education and Engineering}

So what does this all mean? Science educators and engineers must have, and do have, differing goals around science literacy for water. A natural progression of the educational system is highlighted here, where primary and secondary education focus on the more simplistic understandings of the chemistry and biology of water, but mostly tries to promote reverence and curiosity and fascination with water and a desire to learn more. These in turn, may include progression into university to undertake work in this field, but is not limited to this. The joy 
and everyday understanding of water is the overriding goal for education of future publics. What is heavily promoted here is a philosophical change to be imparted to the next generation on the reverence of water and the theoretical and practical tools to use the resource sustainably.

The goal of water sciences education in engineering is to advance the theoretical understandings of the chemistry and biology of water along with responsible resource management and proper application of the laws and policies that govern water management. Foremost is the application of this knowledge in professional situations when called upon to solve problems related to water quality, quantity, or sustainable resource use. Regardless of engineering discipline, expertise or societal role, there is value in supporting and engendering informed publics who are capable of contributing to democratic processes that affect the allocation and management of priority resources like water. Publics who engage in high quality decision-making processes are more likely to make informed decisions in general elections and support higher education opportunities for youth.

The role of engineers in the engendering of water literacy in public groups is less obvious than that for science educators. Our interactions with the public fall into the more informal education model that many engineers, especially young engineers, are not familiar with or aware of.

\section{Conclusion}

Formal science and environmental engineering education play key roles in generating scientific literacy. In science education, primary functions include the curriculum and teacher's understanding, attitudes and beliefs determine what knowledge, skills, and attitudes are produced, packaged and sold in the name of water literacy. In engineering, primary functions relate to appropriate use, allocation, consumption, and treatment of a managed and limited global resource. A review of the ACS and the results of these small case studies highlight a strong focus towards helping students continue to become more familiar and comfortable with the science behind water. Furthermore, there are opportunities for improving the understanding of how water can be conserved in the student's everyday life. In science education and environmental engineering alike, this agenda on its own can generate a superficial level of water literacy, but as per the definitions of what it means to be scientific literate, cannot impart true literacy as it fails to acknowledge the socio-political construction of science and social systems that shape scientific meaning, research and perceptions of progression in science and technology.

Both the ACS and the voices of the participating pre-service teachers suggest that water education within science offers little insight into the role politics, economics, and science itself plays a role in promoting and maintaining social and environmental problems and injustices. The environmental engineering case study results indicate a more comprehensive understanding and value for water resources that is encouraging. However, there remain scientific literacy challenges to be addressed in both formal and informal learning environments for these students. Scientific literacy is only achieved when elements of scientific inquiry, technological problem solving, cultural perspectives, and science, technology, society and environment are comprehended and incorporated.

\section{References}

American Association for the Advancement of Science (AAAS) (1989). Science for All Americans: Project 2061. Washington DC: AAAS.

Australian Curriculum, Assessment and Reporting Authority (ACARA) (2010). The Australian Curriculum: Science. http://www.acara.edu.au/default.asp

AWA/Deloitte. (2011). State of the Water Sector 2011: The View from the Top. http://www.deloitte.com/assets/Dcom-Australia/Local\%20Assets/Documents/Industries/Energy\%20and\%20resources/Wat er/Deloitte_AWA_Water_Report_A_View_From_the_Top.pdf

Beisner, B. (2012). A Plankton Research Gem: The Probable Closure of the Experimental Lakes Area, Canada. Journal of Plankton Research, 34, 849-852.

Canadian Engineering Accreditation Board (CEAB): Engineers Canada (2011). Accreditation Criteria and Procedures. http://www.engineerscanada.ca/files/w_Accreditation_Criteria_Procedures_2011.pdf

Covitt, B., Gunckel, K., \& Anderson, C. (2009). Students’ Developing Understanding of Water in Environmental Systems. Journal of Environmental Education, 40, 37-51.

DeBoer, G. E. (2000). Scientific Literacy: Another Look at Its Historical and Contemporary Meanings and Its Relationship to Science Education Reform. Journal of Research in Science Teaching, 37, 582-601.

Department of Sustainability, Environment, Water, Population and Communities (2011). Annual Report 2010-2011. 
http://www.environment.gov.au/node/13304

de Loë, R. C. (2008). Toward a Canadian National Water Strategy Final Report. Guelph, ON: Canadian Water Resources Association. https://www.cwra.org/images/DocumentsLibraryAndConferenceProceedings/cnws_report_final_2008_06_18.pdf

Dimick, A. S. (2012). Student Empowerment in an Environmental Science Classroom: Toward a Framework for Social Justice Science Education. Science Education, 96, 990-1012.

Eisenhart, M., Finkel, E., \& Marion, S. F. (1996). Creating the Conditions for Scientific Literacy: Are-Examination. American Educational Research Journal, 33, 261-295.

Environment Canada (2004). Threats to Water Availability in Canada. NWRI Scientific Assessment Report Series No. 3 and ACSD Science Assessment Series No. 1. 128 p. Burlington, ON: National Water Research Institute.

Experimental Lakes Area (ELA) (n.d.). Experimental Lakes Area: Research and Education to Protect Freshwater Ecosystems since 1968. http://www.experimentallakesarea.ca/ELA_Website.html

Hess-Biber, S. (2010). Mixed Methods Research: Merging Theory with Practice. New York, NY: Guiltford Press.

Hodson, D. (1999). Going beyond Cultural Pluralism: Science Education for Sociopolitical Action. Science Education, 83, 775-796.

Muro, M., \& Jeffery, P. (2008). A Critical Review of the Theory and Application of Social Learning in Participatory Natural Resource Management Processes. Journal of Environmental Planning and Management, 51, 325-344.

National Research Council (NRC) (1996). National Science Education Standards. Washington DC: National Academy Press.

National Research Council (NRC) (2012). A Framework for K-12 Science Education: Practices, Crosscutting Concepts, and Core Ideas. Washington DC: The National Academies Press.

Reveles, J. M., Cordova, R., \& Kelly, G. J. (2004). Science Literacy and Academic Identity Formulation. Journal of Research in Science Teaching, 41, 1111-1144.

Roth, W.-M., \& Lee, S. (2002). Scientific Literacy as Collective Praxis. Public Understanding of Science, 11, 33-56.

The Alliance for Water Education (2013). Fresh Water Literacy for the Next Generation.

http://allianceforwatereducation.org/ 
Scientific Research Publishing (SCIRP) is one of the largest Open Access journal publishers. It is currently publishing more than 200 open access, online, peer-reviewed journals covering a wide range of academic disciplines. SCIRP serves the worldwide academic communities and contributes to the progress and application of science with its publication.

Other selected journals from SCIRP are listed as below. Submit your manuscript to us via either submit@scirp.org or Online Submission Portal.
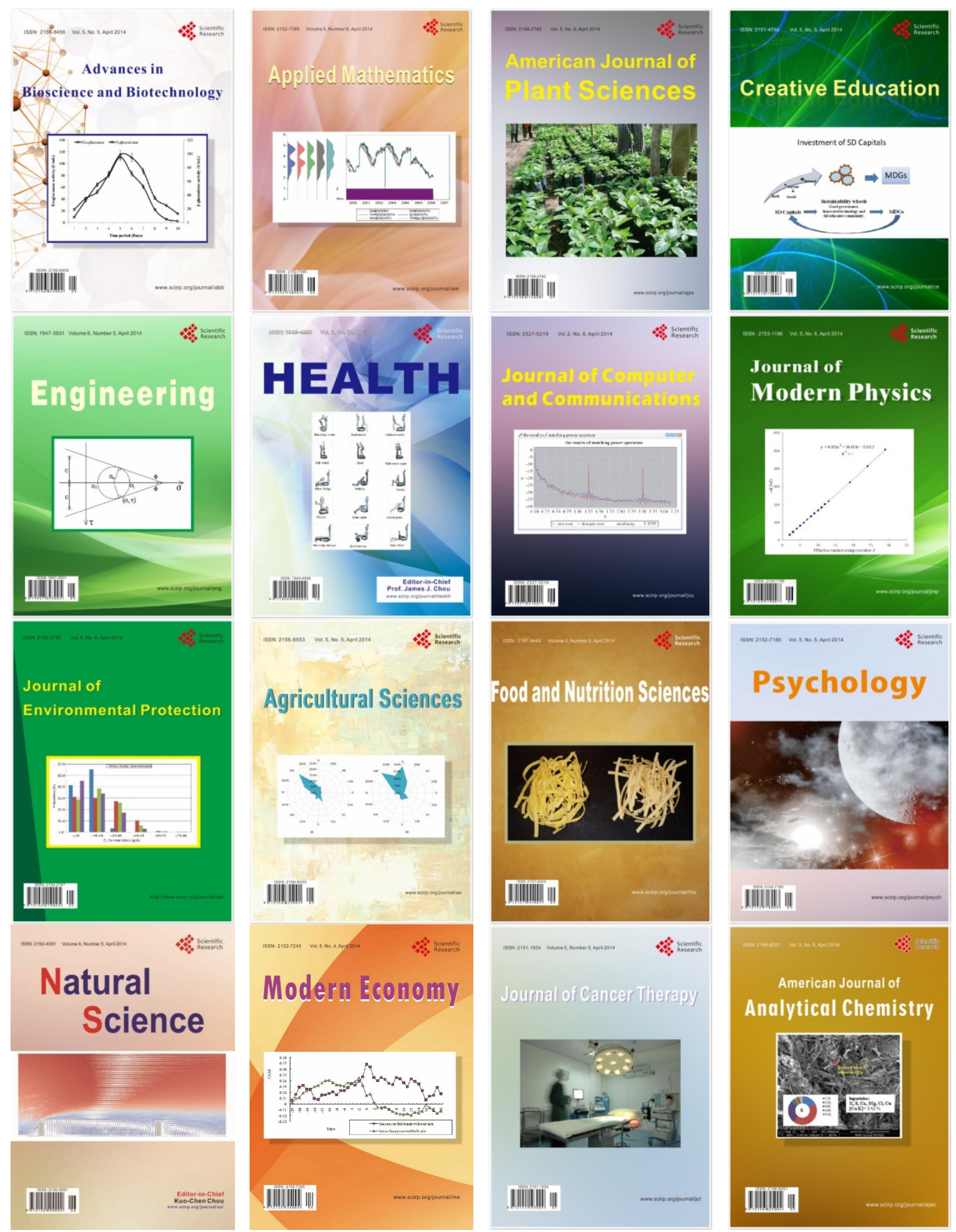